\title{
Stress cardiac magnetic resonance: follow-up of patients with intermediate-high cardiovascular risk
}

\author{
Alberto Esteban-Fernández ${ }^{1 *}$, Isabel Coma-Canella ${ }^{1}$, Gorka Bastarrika-Aleman², Pedro M Azcárte-Aguero \\ From 18th Annual SCMR Scientific Sessions \\ Nice, France. 4-7 February 2015
}

\section{Background}

Stress cardiac magnetic resonance with adenosine (CMR-A) is a valid test to rule out myocardial ischaemia. We follow-up a cohort of patients with CMR-A due to suspected myocardial ischaemia.

\section{Methods}

All the patients with a CMR-A were included between June 2009 and November 2012. The follow-up was done in outpatient cardiology clinic or by phone. We analyze the free-event survival considering as events: acute coronary síndrome (ACS), death for any cause, admission for heart failure (HF) or necessity of revascularization. The statistical analysis was made with SPSS 20.0.

\section{Results}

239 patients were studied (180 male) with a mean age of $66 \pm 10$ years old. One hundred and sixteen $(48.5 \%)$ had previous coronary artery disease, with myocardial infarction in 68 patients. The reason for test referral were: several cardiovascular risk factors $52 \%$, atypical chest pain $33 \%$, typical chest pain $12 \%$, and not conclusive previous test $3 \%$.

The CMR-A was positive for myocardial ischaemia in 83 patients $(35 \%)$ and negative in $156(65 \%)$. The follow-up median was 26 [0-59] months. 53 patients (22\%) had events: 16 patients died (4 because of cardiovascular reasons), 26 had an ACS, 5 were admitted for HF and 21 needed invasive coronariography (18 PCI). There were statistical differences in the Kaplan-Meier survival curves (figure 1) between those with a positive result in

${ }^{1}$ Cardiology Department, Clínica Universidad de Navarra, Pamplona, Spain Full list of author information is available at the end of the article the CMR-A test and those with a negative one (Long Rank test; $\mathrm{p}=0.021$ ).

\section{Conclusions}

In this cohort of patients with an intermediate-high cardiovascular risk, with CMR-A, those with a negative result have fewer events in the follow-up.

\section{Funding}

There is not any specific funding to support this trial.

\section{Authors' details}

${ }^{1}$ Cardiology Department, Clínica Universidad de Navarra, Pamplona, Spain. ${ }^{2}$ Radiology Department, Clínica Universidad de Navarra, Pamplona, Spain.

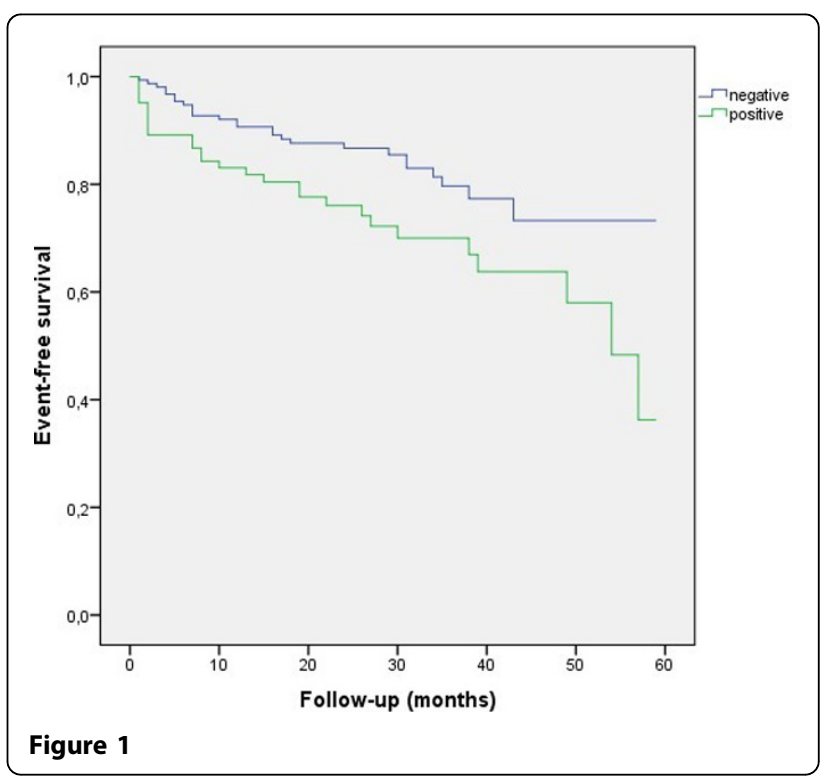


Submit your next manuscript to BioMed Central and take full advantage of:

- Convenient online submission

- Thorough peer review

- No space constraints or color figure charges

- Immediate publication on acceptance

- Inclusion in PubMed, CAS, Scopus and Google Scholar

- Research which is freely available for redistribution

Submit your manuscript at www.biomedcentral.com/submit
C Biomed Central 